National and Global Petroleum Assessment

\title{
Assessment of Undiscovered Oil and Gas Resources of the Lusitanian Basin Province, Portugal, 2016
}

Using a geology-based assessment methodology, the U.S. Geological Survey assessed mean undiscovered, technically recoverable resources of 121 million barrels of oil and 212 billion cubic feet of gas in the Lusitanian Basin Province, Portugal.

\section{Introduction}

The U.S. Geological Survey (USGS) completed an assessment of undiscovered, technically recoverable oil and gas resources within the Lusitanian Basin Province, a geologically complex area of approximately 20,000 square kilometers along the western margin of Portugal (fig. 1). The Lusitanian Basin represents one of the extensional basins formed during the initial stages of Mesozoic Tethyan and Atlantic rifting that preceded the opening of the north-central segment of the Atlantic Ocean. Four phases of Mesozoic extension, two phases of Cenozoic compression, and salt movement are recorded in the rocks of the Lusitanian Basin, resulting in a complexly structured, compartmentalized basin with several subbasins (Rasmussen and others, 1998; Alves and others, 2003; dos Reis and others, 2014a). Organic-rich, thermally mature petroleum source rocks are present in (1) Lower Jurassic Brenha Formation shales (dos Reis and others, 2014b) and possibly present in (2) Silurian shales in the northern part of the basin (Uphoff, 2005).

\section{Geologic Models for Assessment}

For the Lusitanian Basin Province, the USGS defined the Paleozoic-Mesozoic Composite Total Petroleum System (TPS) and the Lusitanian Basin Conventional Reservoirs Assessment Unit (AU) within this TPS. The geologic model for the assessment is for oil and gas generated within Lower Jurassic source rocks during the Cretaceous to have migrated into Jurassic carbonate reservoirs and Cretaceous clastic reservoirs (dos Reis and others, 2014b). The geologic model also includes the potential for oil and gas generated from Silurian source rocks possibly during the Late Jurassic, with this oil largely cracked to gas and migrated into Triassic synrift clastic reservoirs with Jurassic shale seals (Uphoff, 2005). The major source of geologic risk in this $\mathrm{AU}$ is the possible remigration or loss of oil and gas from conventional reservoirs following Cenozoic compression and structural inversion. The area of the Lusitanian Basin Conventional Reservoirs AU north of the Nazaré Fault displays less effects of compression (Rasmussen and others, 1998), and this area of the AU may have less geologic risk than the area south of the fault (fig. 1).

The USGS defined the Lower Jurassic TPS to consist of the Brenha Formation Shale Oil AU and the Brenha Formation Shale Gas AU. The TPS was defined using thermal maturity, source rock thickness, and total organic carbon data from McWhorter and others (2014). The geologic model for the assessment is for generation of oil and minor gas generated within Brenha Formation source rocks during the Cretaceous, with some portion of the oil or gas retained within the source rock following two phases of compression and structural inversion in the Cenozoic. The major source of geologic risk in the Brenha Formation Shale Oil and Brenha Formation Shale Gas AUs is the retention of recoverable oil or gas resources within the source rocks following Cenozoic compression.

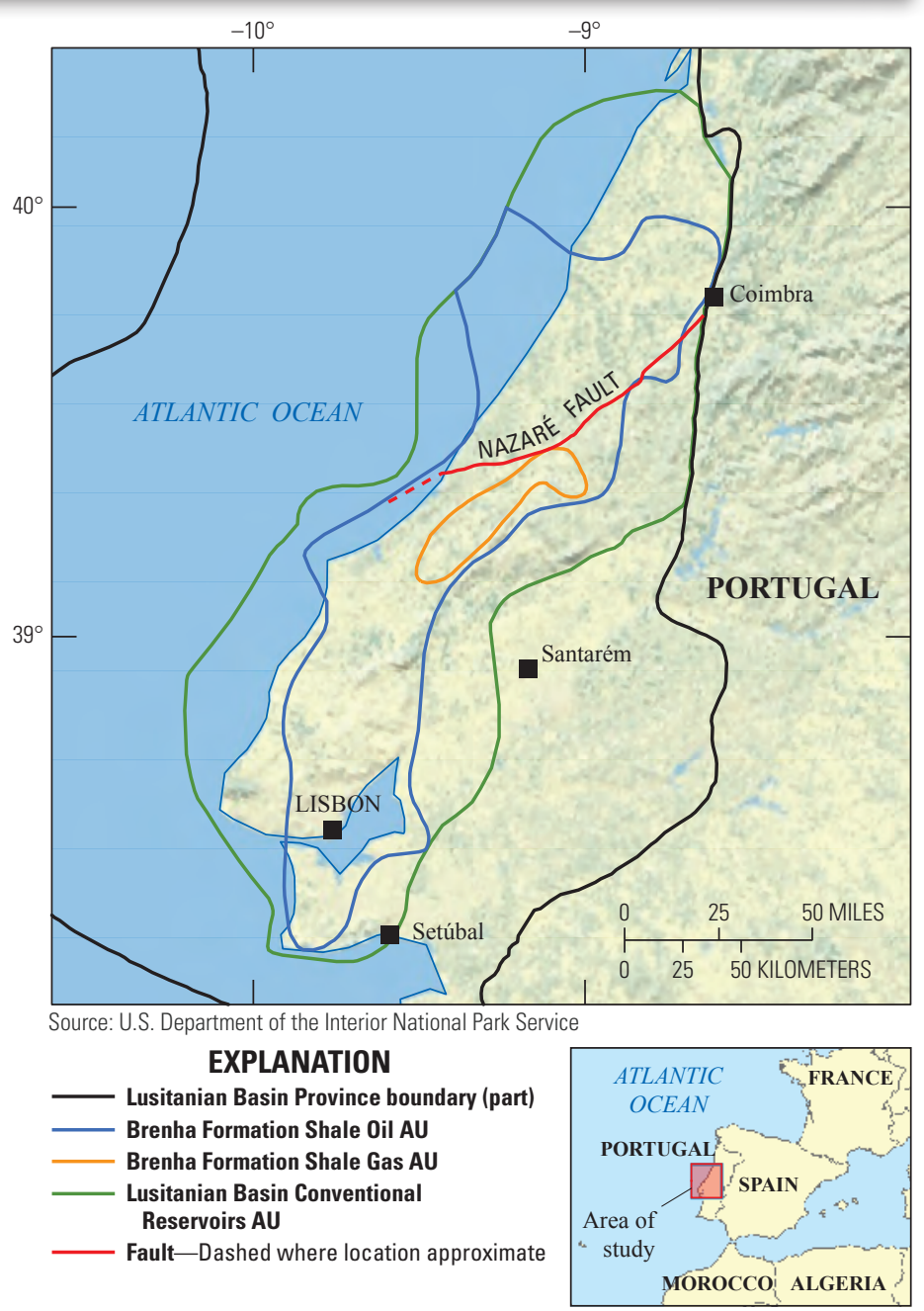

Figure 1. Map showing the location of the Lusitanian Basin and the three assessment units (AU) defined in this study.

Assessment input data for each assessment unit are shown in table 1. Well drainage areas, estimated ultimate recoveries, and success ratios are taken from U.S. shale-oil and shale-gas analogs.

\section{Undiscovered Resource Summary}

The USGS quantitatively assessed undiscovered conventional and continuous oil and gas resources within the Lusitanian Basin Province (table 2). For total undiscovered resources, the estimated means are 121 million barrels of oil (MMBO) with an F95-F5 range from 0 to $393 \mathrm{MMBO}, 212$ billion cubic feet of gas (BCFG) with an F95-F5 range from 0 to 723 BCFG, and 12 million barrels of natural gas liquids (MMBNGL) with an F95-F5 range from 0 to $41 \mathrm{MMBNGL}$. 
Table 1. Key assessment input data for two continuous assessment units and one conventional assessment unit in the Lusitanian Basin Province, Portugal.

[AU, assessment unit; \%, percent; EUR, estimated ultimate recovery per well; MMBO, million barrels of oil; BCFG, billion cubic feet of gas. Well drainage areas, EURs, and well success ratios are taken from U.S. shale-oil and shale-gas analogs. The average EUR input is the minimum, median, maximum, and calculated mean. Shading indicates not applicable]

\begin{tabular}{|c|c|c|c|c|c|c|c|c|}
\hline \multirow[b]{2}{*}{ Assessment input data-Continuous AUs } & \multicolumn{4}{|c|}{ Brenha Group Shale Oil AU } & \multicolumn{4}{|c|}{ Brenha Group Shale Gas AU } \\
\hline & Minimum & Mode & Maximum & $\begin{array}{c}\text { Calculated } \\
\text { mean }\end{array}$ & Minimum & Mode & Maximum & $\begin{array}{c}\text { Calculated } \\
\text { mean }\end{array}$ \\
\hline Potential production area of AU (acres) & 1,000 & 563,000 & $1,876,000$ & 813,333 & 1,000 & 127,000 & 381,000 & 169,667 \\
\hline Average drainage area of wells (acres) & 80 & 160 & 240 & 160 & 120 & 160 & 200 & 160 \\
\hline Success ratio $(\%)$ & 10 & 50 & 90 & 50 & 10 & 50 & 90 & 50 \\
\hline Average EUR (oil, MMBO; gas, BCFG) & 0.01 & 0.04 & 0.1 & 0.043 & 0.1 & 0.3 & 0.7 & 0.319 \\
\hline AU probability & 0.6 & & & & 0.5 & & & \\
\hline \multirow[b]{2}{*}{ Assessment input data-Conventional AU } & \multicolumn{4}{|c|}{ Lusitanian Basin Conventional Reservoirs AU } & \multirow{7}{*}{\multicolumn{4}{|c|}{$\begin{array}{l}\text { Lusitanian Basin Province } \\
\text { Assessment Team } \\
\quad \text { Christopher J. Schenk, Marilyn E. } \\
\text { Tennyson, Timothy R. Klett, Thomas M. } \\
\text { Finn, Tracey J. Mercier, Stephanie B. } \\
\text { Gaswirth, Kristen R. Marra, Phuong A. Le, } \\
\text { Sarah J. Hawkins, Heidi M. Leathers-Miller } \\
\text { and Stanley T. Paxton }\end{array}$}} \\
\hline & Minimum & Mode & Maximum & $\begin{array}{c}\text { Calculated } \\
\text { mean }\end{array}$ & & & & \\
\hline Number of oil fields & 1 & 9 & 30 & 10 & & & & \\
\hline Number of gas fields & 1 & 3 & 10 & 3 & & & & \\
\hline Sizes of oil fields (MMBO) & 5 & 10 & 50 & 11 & & & & \\
\hline Sizes of gas fields (BCFG) & 30 & 60 & 300 & 68 & & & & \\
\hline AU probability & 0.5 & & & & & & & \\
\hline
\end{tabular}

For total continuous shale-oil resources, the estimated means for the Brenha Formation Shale Oil AU are 66 MMBO with an F95-F5 range from 0 to $223 \mathrm{MMBO}$ and $5 \mathrm{BCFG}$ (associated gas) with an F95-F5 range from 0 to $18 \mathrm{BCFG}$. For shale-gas resources, the estimated means for the Brenha Formation Shale Gas AU are 84 BCFG with an F95-F5 range from 0 to 317 BCFG and 4 MMBNGL with an F95-F5 range from 0 to 15 MMBNGL. For total undiscovered conventional resources, the estimated means are 55 MMBO with an F95-F5 range from 0 to 170 MMBO, 123 BCFG with an F95-F5 range from 0 to 388 BCFG, and 8 MMBNGL with an F95-F5 range from 0 to 26 MMBNGL.

Table 2. Assessment results for two continuous and one conventional assessment unit in the Lusitanian Basin Province, Portugal.

[MMBO, million barrels of oil; BCFG, billions of cubic feet of gas; MMBNGL, million barrels of natural gas liquids. Results shown are fully risked estimates. For gas accumulations, all liquids are included under the NGL (natural gas liquids) category. F95 represents a 95-percent chance of at least the amount tabulated. Other fractiles are defined similarly. Fractiles are additive under the assumption of perfect positive correlation. Shading indicates not applicable]

\begin{tabular}{|c|c|c|c|c|c|c|c|c|c|c|c|c|c|c|}
\hline \multirow{3}{*}{$\begin{array}{l}\text { Total petroleum system (TPS) } \\
\text { and assessment units (AUs) }\end{array}$} & \multirow{3}{*}{$\begin{array}{c}\text { AU } \\
\text { proability }\end{array}$} & \multirow{3}{*}{$\begin{array}{l}\text { Accumula- } \\
\text { tion type }\end{array}$} & \multicolumn{12}{|c|}{ Total undiscovered resources } \\
\hline & & & \multicolumn{4}{|c|}{ Oil (MMBO) } & \multicolumn{4}{|c|}{ Gas (BCFG) } & \multicolumn{4}{|c|}{ NGL (MMBNGL) } \\
\hline & & & F95 & $\mathrm{F50}$ & F5 & Mean & F95 & F50 & F5 & Mean & F95 & F50 & F5 & Mean \\
\hline \multicolumn{15}{|c|}{ Paleozoic-Mesozoic Composite TPS } \\
\hline \multirow{2}{*}{ Lusitanian Basin Conventional Resources AU } & \multirow{2}{*}{0.5} & Oil & 0 & 36 & 170 & 55 & 0 & 7 & 35 & 11 & 0 & 0 & 1 & 0 \\
\hline & & Gas & & & & & 0 & 80 & 353 & 112 & 0 & 5 & 25 & 8 \\
\hline Total undiscovered conventional resources & & & $\mathbf{0}$ & 36 & 170 & 55 & $\mathbf{0}$ & 87 & 388 & 123 & $\mathbf{0}$ & 5 & 26 & 8 \\
\hline \multicolumn{15}{|c|}{ Lower Jurassic TPS } \\
\hline Brenha Formation Shale Oil AU & 0.6 & Oil & 0 & 43 & 223 & 66 & 0 & 3 & 18 & 5 & 0 & 0 & 0 & 0 \\
\hline Brenha Formation Shale Gas AU & 0.5 & Gas & & & & & 0 & 0 & 317 & 84 & 0 & 0 & 15 & 4 \\
\hline Total undiscovered continuous resources & & & $\mathbf{0}$ & 43 & 223 & 66 & $\mathbf{0}$ & 3 & 335 & 89 & $\mathbf{0}$ & $\mathbf{0}$ & 15 & 4 \\
\hline Total undiscovered resources & & & 0 & 79 & 393 & 121 & 0 & 90 & 723 & 212 & $\mathbf{0}$ & 5 & 41 & 12 \\
\hline
\end{tabular}

\section{References}

Alves, T.M., Gawthorpe, R.L., Hunt, D.W., and Monteiro, J.H., 2003, Post-Jurassic tectono-sedimentary evolution of the northern Lusitanian Basin (western Iberian margin): Basin Research, v. 15, p. 227-249.

dos Reis, R.P., Pimentel, Nuno, and Garcia, António, 2014a, The evolution of the Atlantic margin of Iberia as recorded in the Lusitanian Basin (Portugal): American Association of Petroleum Geologists Search and Discovery Article \#30370, 21 p., accessed September 15, 2016, at http://www.searchanddiscovery.com/pdfz/documents/2014/30370reis/ndx_reis.pdf.html.

dos Reis, R.P., Pimentel, Nuno, Cardoso, Fátima, and Teixeira, Bernardo, 2014b, Petroleum systems and thermal modeling of the western Iberian margin - From the onshore Lusitanian Basin to the deep offshore Peniche Basin: American Association of Petroleum Geologists Search and Discovery Article \#10679, 25 p., accessed September 15, 2016, at http:/www.searchanddiscovery.com/pdfz/documents/2014/10679reis/ndx_reis.pdf.html.
McWhorter, Sean, Torguson, William, and McWhorter, Ron, 2014, Characterization of the Lias of the Lusitanian Basin, Portugal, as an unconventional resource play: American Association of Petroleum Geologists Search and Discovery Article \#80376, 9 p., accessed September 15, 2016, at http://www.searchanddiscovery.com/documents/2014/80376mcwhorter/ndx_mcwhorter.pdf.

Rasmussen, E.S., Lomholt, Steen, Anderson, Claus, and Vejbaek, O.V., 1998, Aspects of the structural evolution of the Lusitanian Basin in Portugal and the shelf and slope area offshore Portugal: Tectonophysics, v. 300, p. 199-225.

Uphoff, T.L., 2005, Subsalt (pre-Jurassic) exploration play in the northern Lusitanian Basin of Portugal: American Association of Petroleum Geologists Bulletin, v. 89, no. 6, p. 699-714.

\section{For More Information}

Assessment results also are available at the USGS Energy Resources Program Web site at http://energy.usgs.gov. 